\title{
Settlement of Strip Footing on Reinforced Geocell- Clay
}

Gihan. E. Abdelrahman.

Khaled. R. Khater.

Rania. H. Mohamed.

\begin{abstract}
The technique of reinforcing soil for foundation improvement is well established. In this paper, parametric study using finite element analysis PLAXIS, 8.2 has been introduced to discuss the effect of elastic modulus of clay on settlement in clay beneath center and corner of strip footing at thickness 0.3 and $1.5 \mathrm{~m}$ without geogrid layer. Secondly case study the effect of elastic modulus of sand, elastic modulus of clay, and thickness of strip footing on relative settlement $S_{s-c} / S_{c}$ (settlement in sand overlay clay over settlement in clayey soil) beneath center and corner of strip footing without geogrid. Third case study the effect of one layer geogrid depth and thickness of strip footing on relative settlement beneath center and corner of strip footing. The results indicated that increasing elastic modulus of clay decreases settlement beneath center and corner of strip footing without geogrid. The settlement in case of sand overlay clay beneath center and corner of strip footing without geogrid decreases with increasing elastic modulus of sand over clay. In case of using geogrid, sand layer was used overlay the clay bed. In addition, the relative settlement beneath center and corner of strip footing with geogrid increases with increasing depth of geogrid. It has been observed that the difference in settlement between points $A$ and $B$ in thickness $0.3 \mathrm{~m}$ greater than $1.5 \mathrm{~m}$ because of strip footing rigidity with soil.
\end{abstract}

Keywords - Strip footing, Sand, Clay, finite element, Geogrid.

\section{Introduction}

The reinforced soil bed opens up the possibilities of founding civil engineering structures on soil conditions hitherto not suitable. Introduction of reinforced soil below the footing can increase the bearing capacity substantially.

Many materials were used as a reinforcing inclusion in the soil continuum, such as bamboo, smooth steel strips, and ribbed steel strips and geosynthetics materials. The vast majority of the geosynthetic materials are currently made of polymer- based materials.

Gihan.E.Abdelrahman, Professor Civil Engineering Department

Faculty of Engineering, Fayoum University

Fayoum, Egypt

Khaled. R. Khater, Assistant Professor, Civil Engineering Department Faculty of Engineering, Fayoum University Fayoum, Egypt

Rania.H. Mohamed, Post Graduate Student, Civil Engineering Department Faculty of Engineering, Fayoum University
The last two decades witnessed extended use of reinforcing geosynthetics due to numerous advantages (Koerner, 1990) including that : it could be installed rapidly, provide savings in construction cost, and environmental aspects. The most common geosynthetic products, which used for reinforcement, are woven geotextiles and geogrid in the reinforcement propose. Geogrid sheets is highly recommended than using woven geotextile, as it could develop both friction and bearing stresses (Milligan et al. 1986) but the woven geotextile could develop only frictional stress on the soil/geosynthetics interface surface.

In general, settlement is the governing criterion for designing a footing resting on weak granular material. Usually, for a given settlement, the load that a footing can carry is obtained either by using plate load test data or standard penetration test. However, a novel method proposed by Sharan (1977) and Prakash et al (1984) based on constitutive laws of soil, which gives pressure settlement characteristics of a footing resting on soil. Sireesh, (2010) studied the behavior of geocell reinforced foundation beds using experimental and predictive model. He concluded that the predicted footing settlements of geocell reinforced clay beds are observed to be on conservative side at footing settlement ratios higher than $10 \%$.

The geocell is one of the various recent forms of reinforced soil used in civil engineering construction. The term "geocell" refers to a polymeric, honeycomb like cellular material. A structure of these cells interconnected by joints to form a cellular network could be used for the confinement of soil. Geocells could be either manufactured on site using planar geosynthetics, preferably geogrids, or could be purchased ready-made. These geocells completely encase the soil and provide all-round confinement, thus preventing the lateral spreading of the soil. Because of this, the soilgeocell layer acts as a stiff mat, distributing the load over a much larger area of the subgrade soil. This helps in reducing vertical and lateral deformations of the foundation soil to a large extent besides increasing the overall bearing capacity of the foundation soil.

This paper presents parametric study based on finite element analysis to model strip footing on geocell-clay With and Without Reinforcement to investigate the effect of different elastic modulus of clay, elastic modulus of sand, depth of geogrid with footing, and thickness of strip footing on settlement beneath center and corner of strip footing. 


\section{Finite Element Modeling}

In the current study, the analysis was performed using the finite element program Plaxis 8.2 software package (Bringkgreve and Vermeer, 1998). Plaxis is capable of handling a wide range of geotechnical problems such as deep excavations, tunnels, slopes, earth structures, and shallow foundation such as strip footing. Two dimensional plain strain model was used in the analysis.

\section{A. Geometry and Boundary Conditions}

The non-linear finite element program PLAXIS, which takes into account the mechanical behavior of strip footing on reinforced soil and is able to calculate the settlement at two points $\mathrm{A}$ and $\mathrm{B}$. Point (A) is under the center of footing, while point (B) is under the corner. Typical geometry of the strip footing in case of clay only without grogrid is shown in figure (1), typical geometry of the strip footing in case of clay with geocell sand without geogrid is shown in figure (2), and typical geometry of the strip footing in case of clay with geocell sand with one geogrid at different depth (d) is shown in figure (3).

The constant length of geogrid equal $6 \mathrm{~m}$. The constant parameters are the width of strip footing equal $2 \mathrm{~m}$, load equal 10 ton, and elastic modulus of concrete equal to (20000) $\left(\mathrm{MN} / \mathrm{m}^{2}\right)$. The finite element mesh is composed of 15-node isoperimetric triangular elements. The mesh coarseness was set as "Very fine". Horizontal fixities (rollers) were applied to the stable face which allows the wall to settle at in the vertical direction but prohibited the nodes along the boundary from moving laterally. Total fixities were placed at bottom of the foundation. Plane strain was assumed to solve the three-dimensional problem with a two-dimensional analysis to simulate the real construction process of strip footing.

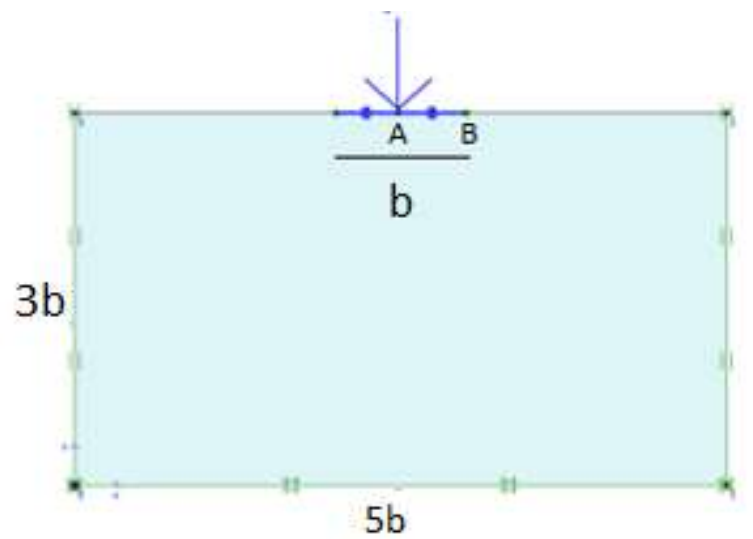

Figure 1: Case of clay only without geogrid

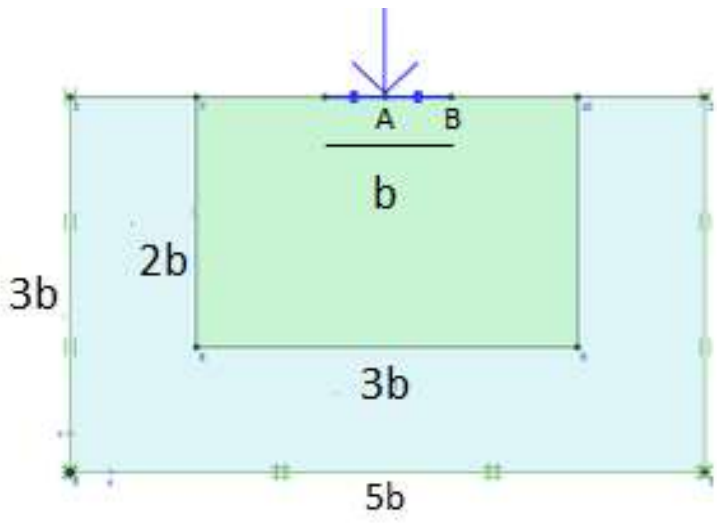

Figure 2: Case of clay with geocell sand without geogrid

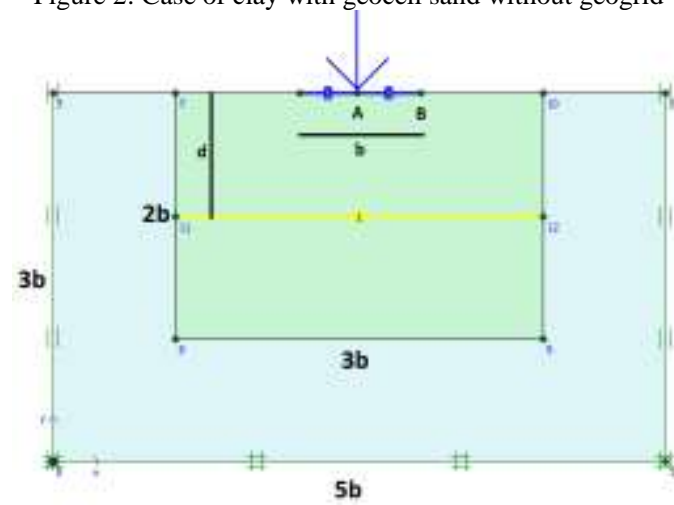

Figure 3: Case of clay with geocell sand with one geogrid at different depth (d)

\section{B. Soil Properties}

The Mohr-Coulomb constitutive model was used to model the stress strain behavior of soils. Table (1) shows the soils parameters used in the analysis. The Elastic-Plastic Mohr-Coulomb Model named (MC-model) represents a "first order" approximation of soil behavior. This model involves five input parameters Young's modulus $\mathrm{E}$; Poisson's ratio v; Cohesion C; Friction angle $\varphi$; Dilatancy angle $\Psi$. For each soil layer, a constant average stiffness could be used. PLAXIS allows for the input of alternative stiffness modulus, such as the shear modulus, G, and oedometer, $E_{\text {oed }}$. This stiffness modulus relate to Young's modulus according to Hook's law of isotropic elasticity, which involves Poisson's ratio. In general when using MohrCoulomb Model the use of higher value of $v$ is recommended but for unloading problem, it may be realistic to use low initial value of $v$.

\section{Reinforcement Properties}

The reinforcements were modeled as line elements with a normal stiffness but with no bending stiffness. In addition, line elements could only sustain tensile forces but no compression. An elastic model was selected to model the breakage of reinforcement. The reinforcement properties used in the modeling is EA (Axial Stiffness) $=1.80(\mathrm{MN} / \mathrm{m})$. 
Proc. of the Third Intl. Conf. Advances in Civil, Structural and Mechanical Engineering- CSM 2015

Copyright (C) Institute of Research Engineers and Doctors, USA .All rights reserved.

ISBN: 978-1-63248-062-0 doi: 10.15224/ 978-1-63248-062-0-77

TABLE (1) soil properties

\begin{tabular}{|c|c|c|}
\hline Type & Parameter & Value \\
\hline \multirow{4}{*}{ Clay } & Unit weight, $\gamma,\left(\mathrm{N} / \mathrm{m}^{3}\right)$ & 17800 \\
\cline { 2 - 3 } & Peak friction angle, $\Phi,($ deg. $)$ & 0 \\
\cline { 2 - 3 } & Cohesion, c, $\left(\mathrm{N} / \mathrm{m}^{2}\right)$ & 12500 \\
\cline { 2 - 3 } & Secant stiffness, $\mathrm{E}_{50}{ }^{\text {ref }},\left(\mathrm{N} / \mathrm{m}^{2}\right)$ & Variable \\
\hline \multirow{4}{*}{ Sand } & Unit weight, $\gamma,\left(\mathrm{N} / \mathrm{m}^{3}\right)$ & 17000 \\
\cline { 2 - 3 } & Peak friction angle, $\Phi,($ deg. $)$ & 35 \\
\cline { 2 - 3 } & Angle of dilatancy, $\Psi,($ deg.) & 5 \\
\cline { 2 - 3 } & Cohesion, $\mathrm{c},\left(\mathrm{N} / \mathrm{m}^{2}\right)$ & 0 \\
\cline { 2 - 3 } & Secant stiffness, $\mathrm{E}_{50}{ }^{\text {ref }},\left(\mathrm{N} / \mathrm{m}^{2}\right)$ & Variable \\
\hline
\end{tabular}

TABLE 2. Parametric study series

\begin{tabular}{|c|c|c|c|}
\hline $\begin{array}{c}\text { Studied } \\
\text { Parameters }\end{array}$ & $\begin{array}{c}\mathbf{E}_{\text {clay }} \\
\mathbf{M N} / \mathbf{m}^{2}\end{array}$ & $\begin{array}{c}E_{\text {xand }} \\
M N / m^{2}\end{array}$ & $\begin{array}{c}\text { Variable } \\
\text { parameters }\end{array}$ \\
\hline \multirow{2}{*}{$\begin{array}{l}\text { Settlement } \\
\text { in clay, } S_{\mathrm{c}} \text { at } \\
\text { point }(\mathrm{A} \& \mathrm{~B})\end{array}$} & \multirow[t]{2}{*}{ - } & \multirow[t]{2}{*}{-} & $\begin{array}{c}E_{\text {elly }}=0.5,1,2,3, \\
6\left(\mathrm{MN} / \mathrm{m}^{2}\right)\end{array}$ \\
\hline & & & $\mathrm{t}_{\mathrm{i}}=0.3,1.5(\mathrm{~m})$ \\
\hline \multirow{6}{*}{$\begin{array}{l}\text { Relative } \\
\text { Settlement } \\
\mathrm{S}_{\mathrm{s}-\mathrm{c}} / \mathrm{S}_{\mathrm{c}} \\
\text { at points A } \\
\text { and B }\end{array}$} & \multirow{2}{*}{2} & \multirow{2}{*}{ - } & $\begin{array}{c}E_{\operatorname{man} d}=10,20,40 \\
60,80\left(\mathrm{MN} / \mathrm{m}^{2}\right) \\
\end{array}$ \\
\hline & & & $\begin{array}{c}\mathrm{t}_{\mathrm{p}}=0.3,0.5,0.8,1.5 \\
(\mathrm{~m})\end{array}$ \\
\hline & \multirow{2}{*}{3} & \multirow{2}{*}{ - } & $\begin{array}{l}E_{\text {and }}=30,50,60 \\
90,120\left(\mathrm{MN} / \mathrm{m}^{2}\right)\end{array}$ \\
\hline & & & $\begin{array}{c}\mathrm{t}_{\mathrm{p}}=0.3,0.5,0.8,1.5 \\
(\mathrm{~m})\end{array}$ \\
\hline & \multirow{2}{*}{2} & \multirow{2}{*}{40} & $\begin{array}{l}\mathrm{d}=0.25 \mathrm{~b}, 0.5 \mathrm{~b} \\
0.75 \mathrm{~b}, \mathrm{~b}, 1.25 \mathrm{~b}\end{array}$ \\
\hline & & & $\begin{array}{c}\mathrm{L}_{\mathrm{s}}=6 \mathrm{~m}, \mathrm{t}_{\mathrm{f}}=0.3 \\
1.5(\mathrm{~m})\end{array}$ \\
\hline
\end{tabular}

\section{Results and Discussion}

A numerical study was carried out on plane strain model of strip footing Resting on Reinforcement soil. The effect of elastic modulus of clay on settlement in clay at points A and $\mathrm{B}$ at thickness of strip $(0.3 \& 1.5) \mathrm{m}$ note that this case without geogrid. The effect of elastic modulus of sand on settlement in sand overlay clay/ settlement in clay at point A and $\mathrm{B}$ at different thickness of strip note that this case without geogrid. The effect of depth of geogrid with footing (d) on relative settlement at point $\mathrm{A}$ and $\mathrm{B}$ at thickness of strip (0.3\&1.5) m. Table (2) summarizes all parametric study series performed in this study.

\section{A. Effect of Elastic Modulus of Clay on Settlement in Clay at Points $A$ and $B$}

The settlement is defined as the vertical displacement. Settlement depend on the density of soil and the applied load. The effect of varying elastic modulus of clay on settlement in clay at points A and B at thickness of strip $(0.3 \& 1.5) \mathrm{m}$, length of geogrid is ineffective and depth of geogrid with footing (d) is ineffective as shown in Figure 4.I and Figure 4.II. It is noticed for thickness $(0.3 \& 1.5) \mathrm{m}$ that the settlement in clay at points $\mathrm{A}$ and $\mathrm{B}$ decreases significantly with increasing the elastic modulus of clay. In general the increase elastic modulus lead to soil become dense and this lead to decrease void ratio Thus decrease settlement. Also it is noticed for thickness $(0.3 \& 1.5) \mathrm{m}$ that the settlement in clay at point (B) is less than the settlement in clay at point (A) at any elastic modulus this is logical because the point $\mathrm{A}$ under load immediately but point $\mathrm{B}$ far from load. It has been observed that the difference in settlement between points $\mathrm{A}$ and $\mathrm{B}$ in thickness 0.3 greater than 1.5 this is logical because 0.3 near to Flexibility but 1.5 near to rigidity.
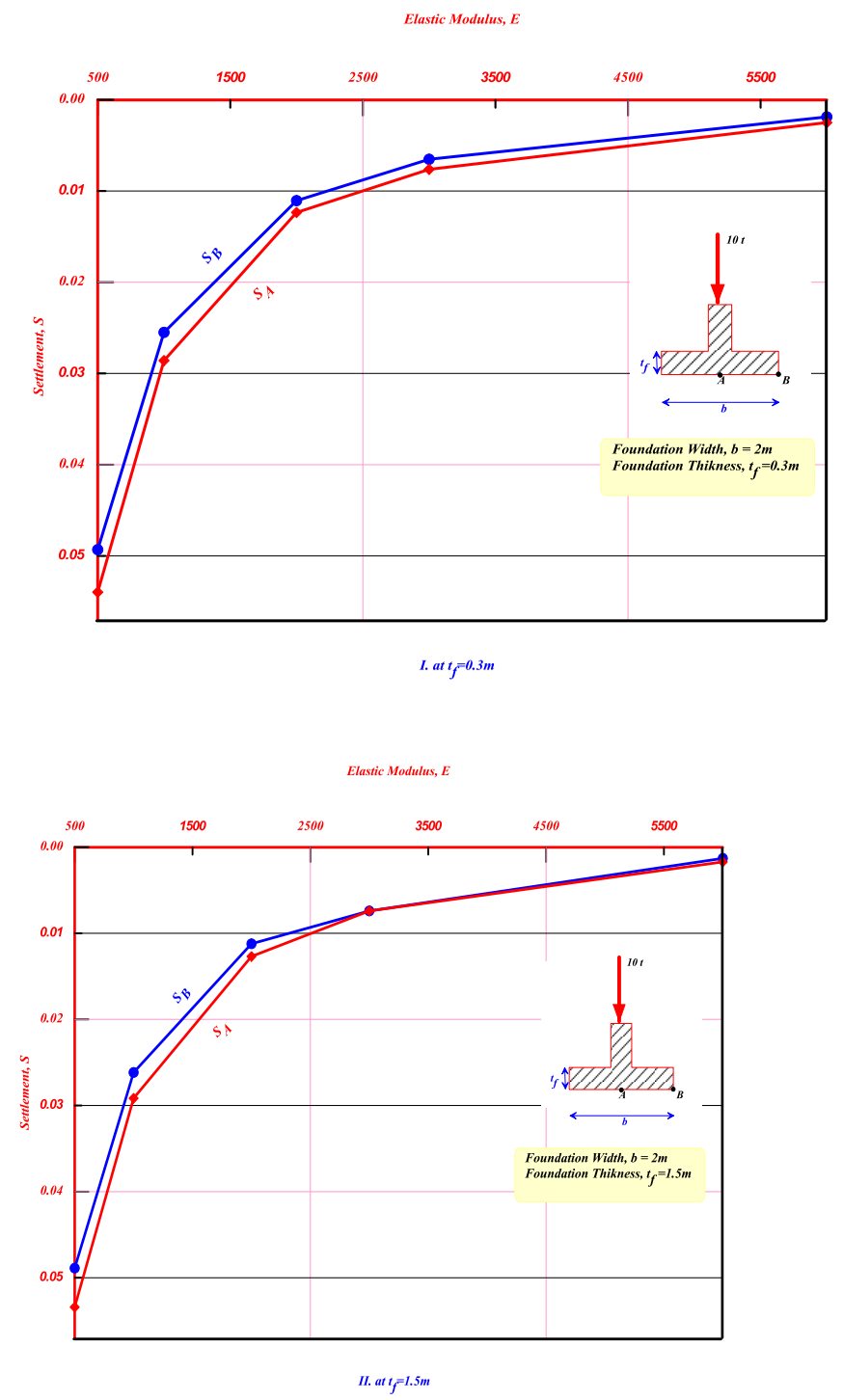

Figure4: Relationship between settlement and elastic modulus in clay only 


\section{B. Effect of Elastic Modulus of Sand, and Clay, with Thickness of Strip Footing on Relative Settlement at Points $A$ and $B$}

The effect of varying elastic modulus of sand, the effect of varying elastic modulus of clay, the effect of varying thickness of strip footing, length of geogrid is ineffective and depth of geogrid with footing (d) is ineffective as shown in Figures 5.I to 5.IV on relative settlement at points A and $\mathrm{B}$ note that for each figure elastic modulus of clay constant but varying elastic modulus of sand will be study. It is noticed for any thickness that the relative settlement at points A and B decreases significantly with increasing the elastic modulus of sand. In general the increase elastic modulus lead to soil become dense and this lead to decrease void ratio Thus decrease settlement. It has been observed that at the same point in any relationship was found when increasing depth decrease the settlement and this logical. The important note in this part is that the modulus of elasticity change clay significant impact on the value of the settlement. In the case of increasing the modulus of elasticity of clay coefficient from 2 to $3\left(\mathrm{MN} / \mathrm{m}^{2}\right)$ the value of the settlement less than half. Note that symbols $S_{A C}$, and $S_{B C}$ in the following figures Refers to settlement at point $A$ and $\mathrm{B}$ in clay only.
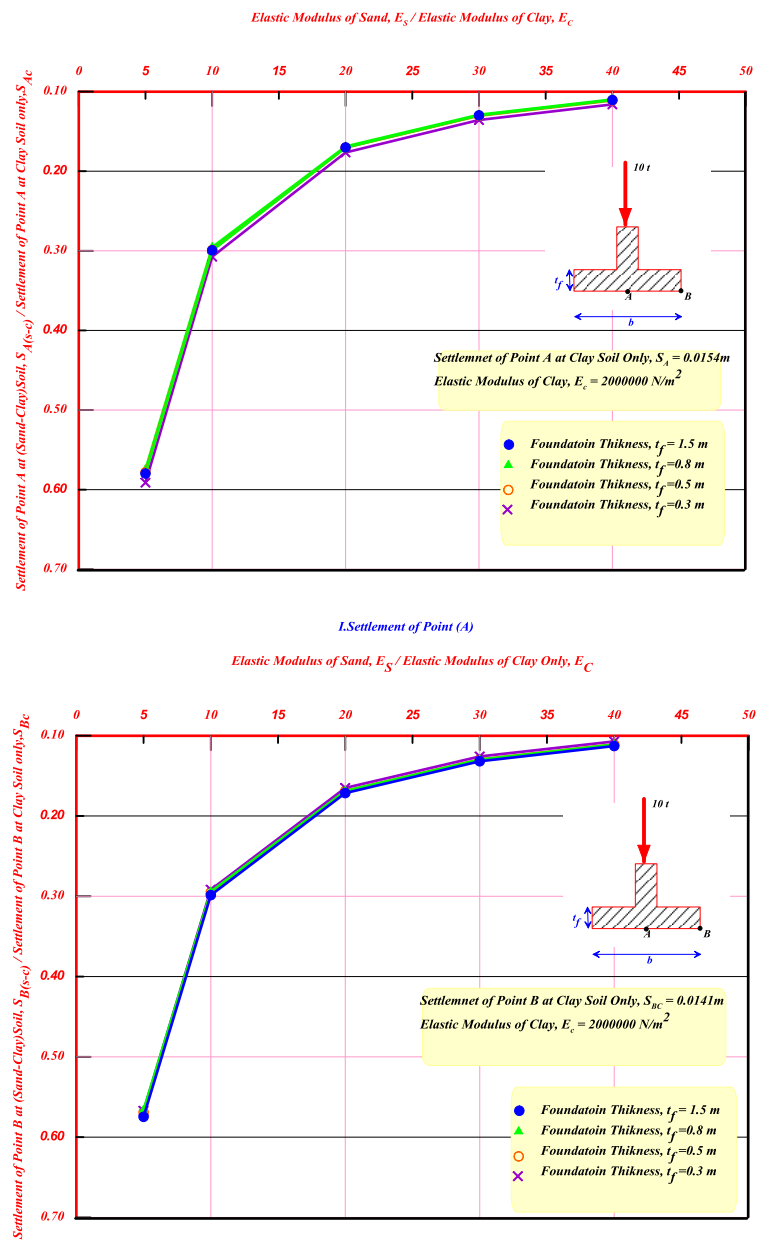
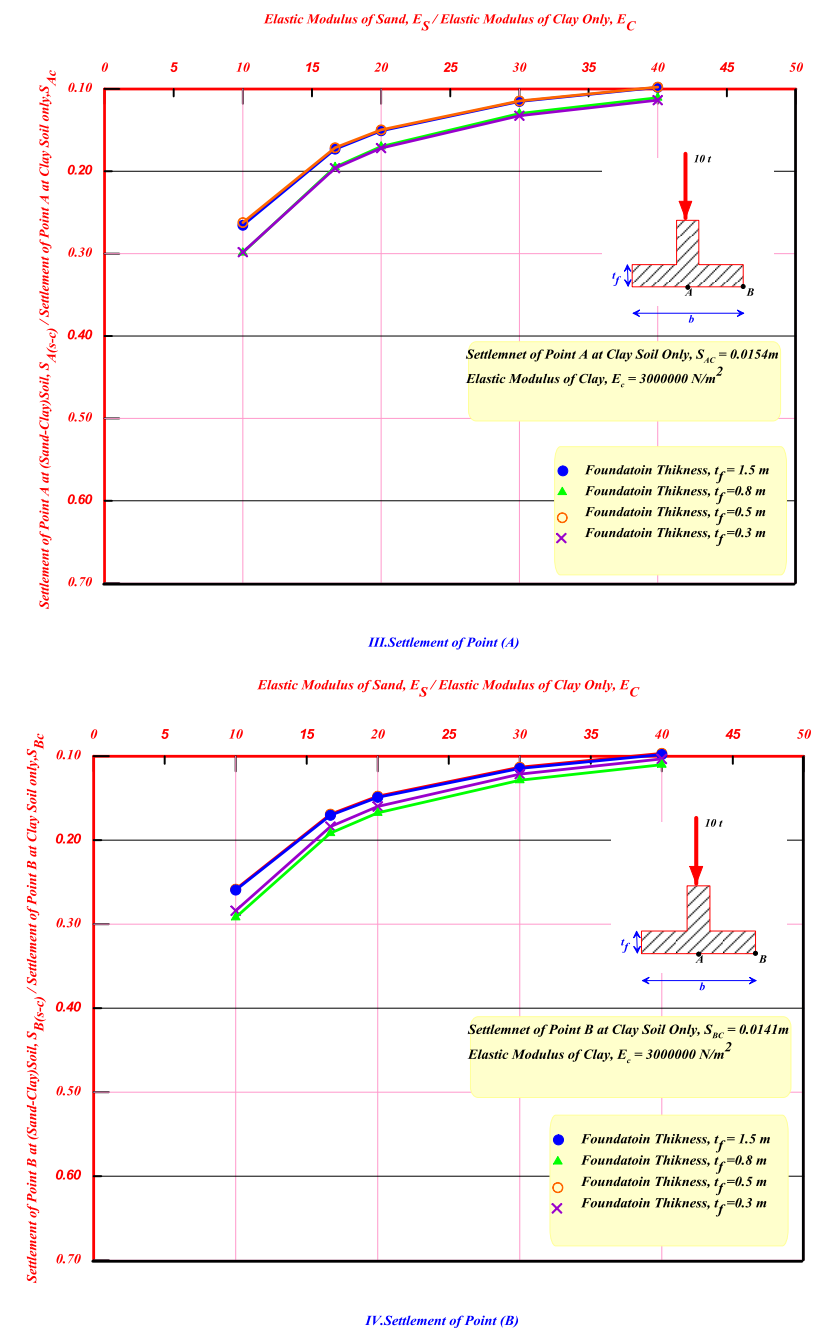

Figure 5: Relationship Between Point (A) and (B) Settlement and $E_{\text {gand }} / E_{\text {clay }}$ at $\mathrm{E}_{\mathrm{c}}=2$, and $3\left(\mathrm{MN} / \mathrm{m}^{2}\right)$.

\section{Effect of Geogrid Depth with Footing and Thickness of Strip Footing on Relative Settlement at Points $A$ and $B$}

The effect of varying depth of geogrid with footing, the effect of varying thickness of strip footing, elastic modulus of sand equal $40\left(\mathrm{MN} / \mathrm{m}^{2}\right)$, the elastic modulus of clay equal $2\left(\mathrm{MN} / \mathrm{m}^{2}\right)$ and length of geogrid equal $6 \mathrm{~m}$ as shown in Figure 6.I and Figure 6.II on relative settlement at points $\mathrm{A}$ and B. It is noticed that the settlement increases significantly with increasing the depth of geogrid with footing. This is logic because the increase of depth decrease the effect of stress. It is certainly the presence of the geogrid near the footing makes it bear more stress and decreases the settlement. 
Proc. of the Third Intl. Conf. Advances in Civil, Structural and Mechanical Engineering- CSM 2015

Copyright (C) Institute of Research Engineers and Doctors, USA .All rights reserved.

ISBN: 978-1-63248-062-0 doi: 10.15224/ 978-1-63248-062-0-77

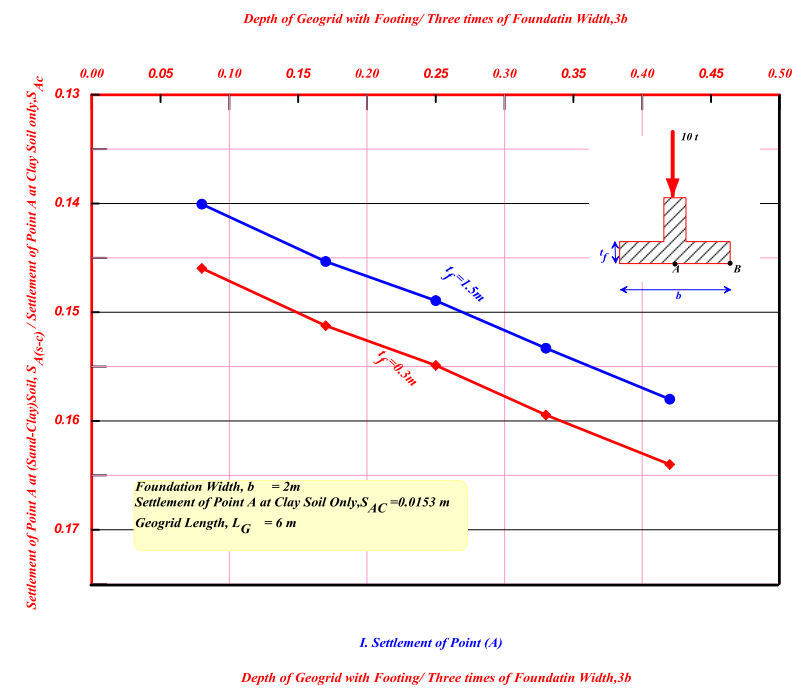

It has been observed that the difference in settlement between strip footing center (point A) strip footing corner (point $\mathrm{B}$ ) in footing thickness 0.3 greater than 1.5. this is because of strip footing rigidity.

\section{References}

[1] G. W. E. Milligan, R. J. Fanin, D. M. Farrar. "Multilayer feed-forward networks are universal approximators." Neural Networks. Vol.2.359366, 1986.

[2] R.Bringkgreve, P.Vermeer, PLAXIS finite element code for soiland rock analysis.Version 7 Plaxis, B.V., Netheriands, 1998.

[3] RM. Koerner, "Determination of the Long-Term Design Strength of Stiff Geogrids," GRI Standard Practice GG4 (a), 1990.

[4] S. Prakash, S. Saran, And U. N. Sharan, Footings and constitutive laws. Journal of geotechnical engineering, ASCE, 110(10), 1984, pp 1473-1487,

[5] Saride, Sireesh, "Settlement Prediction of Geocell-Reinforced Clay Foundations," Indian Geotechnical Conference-GEOtrendz, 2010.

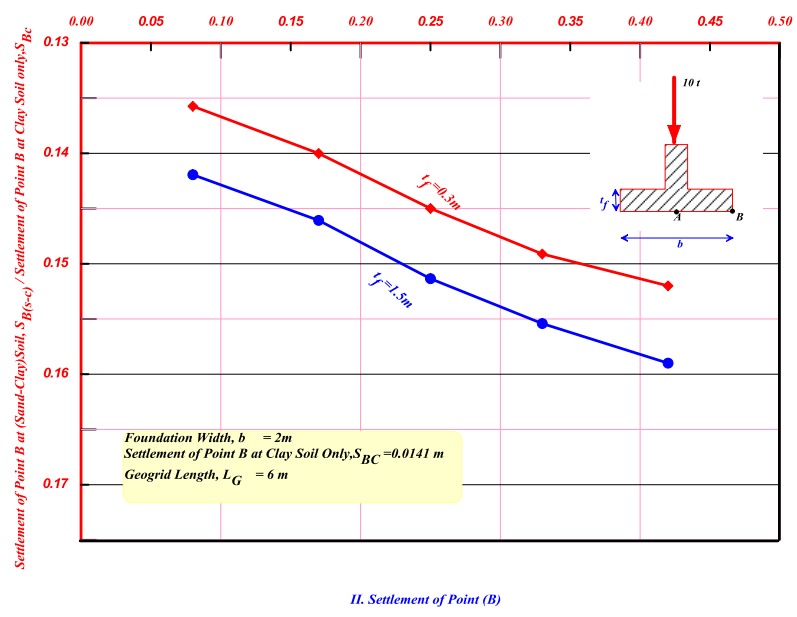

[6] U. N. Sharan, Pressure-settlement characteristics of surface footings from constitutive laws. Ph. D. Thesis, University of Roorkee, Roorkee (U.P.), India, 1977.

Figure 6: Relationship Between Point (A) and t (B) Settlement and Geogrid Depth with Geogrid Length $=6 \mathrm{~m}$

\section{Conclusion}

Finite element study was carried out by conduction a series of plane strain analyses to model parametric study which allow understanding the settlement of strip footing. It is concluded that increasing elastic modulus of clay at case of clay only and elastic modulus of sand in sand and clay case decreases the settlement. In addition, increasing depth of geogrid with footing increases the settlement.

The settlement of strip footing at case of geocell sand without, and with geogrid equal to $17.65 \%$, and $15.12 \%$ respectively at strip footing center (point $\mathrm{A}$ ) and equal $16.52 \%$, and $14 \%$ respectively at strip footing corner (point B) from the settlement of strip footing at case of clay only. at (footing thickness equal $0.3 \mathrm{~m}, E_{\text {clay }}$ equal $2\left(\mathrm{MN} / \mathrm{m}^{2}\right)$, $E_{\text {gand }}$ equal $40\left(\mathrm{MN} / \mathrm{m}^{2}\right)$, depth of one geogrid from strip footing equal $0.5 \mathrm{~m}$, and length of one geogrid equal $6 \mathrm{~m}$ ) .

The settlement of strip footing at case of geocell sand without, and with geogrid equal $16.9 \%$, and $14.4 \%$ respectively at point (A), and equal $16.9 \%$, and $14.9 \%$ respectively at point (B) from the settlement of strip footing at case of clay only, these results at footing thickness equal $1.5 \mathrm{~m}, E_{\text {clay }}$ equal $2\left(\mathrm{MN} / \mathrm{m}^{2}\right), E_{\text {sand }}$ equal $40\left(\mathrm{MN} / \mathrm{m}^{2}\right)$, depth of one geogrid from strip footing equal $0.5 \mathrm{~m}$, and length of one geogrid equal $6 \mathrm{~m}$. 